\title{
Airline Economics - Planning and Key Performance Indicators Practical Guide for Students
}

\author{
Istvan Simon Hungary
}

This paper is a practical guide to assist students in understanding the Key Performance Indicators of airline economics and the relationships between them. This assistance will be materialised in the form of an example of calculating and presenting the core economic indicators of a hypothetical airline. A simplified one-year operational and financial plan will be assembled. This guide is intended to be used as the basis for class discussions.

Keywords: profit, planning, yield, network effect

\section{INTRODUCTION}

There are numerous students among my readers on the Academia.edu web site. I have decided to prepare a practical guide to assist students in understanding the Key Performance Indicators of airline economics and the relationships between them. This assistance will be materialised in the form of an example of calculating and presenting the core economic indicators of a hypothetical airline. The equations applied in this paper are laid down in my previous paper (AIRLINE PROFIT EQUATION REVISED Back to the basics) published on the Academia.edu website. To be consistent with my previous paper as much as possible, I use the same notation (see Appendix 5.1) throughout the remainder of this paper.

I will set up a simplified airline. All the data are estimations based on certain assumptions. The student may replace them with real data. Having set up my airline, I put together a one-year operational and financial plan. As a simplification, I disregard detailed airline schedule and cost calculations in the plan.

The planning phase is followed with a What-If analysis to show the relationships between the Profit Drivers (load factor, yield and unit cost).

The name of this hypothetical airline is "MyAir"; I concentrate on the passenger transportation sector in this paper.

\section{SETTING UP THE AIRLINE}

\section{Network}

Let's choose a simple hub and spoke network with six airports connected from Hub A (Figure 1). 
FIGURE 1

LENGTH OF ARROWS REFLECTS THE DISTANCE FROM THE HUB

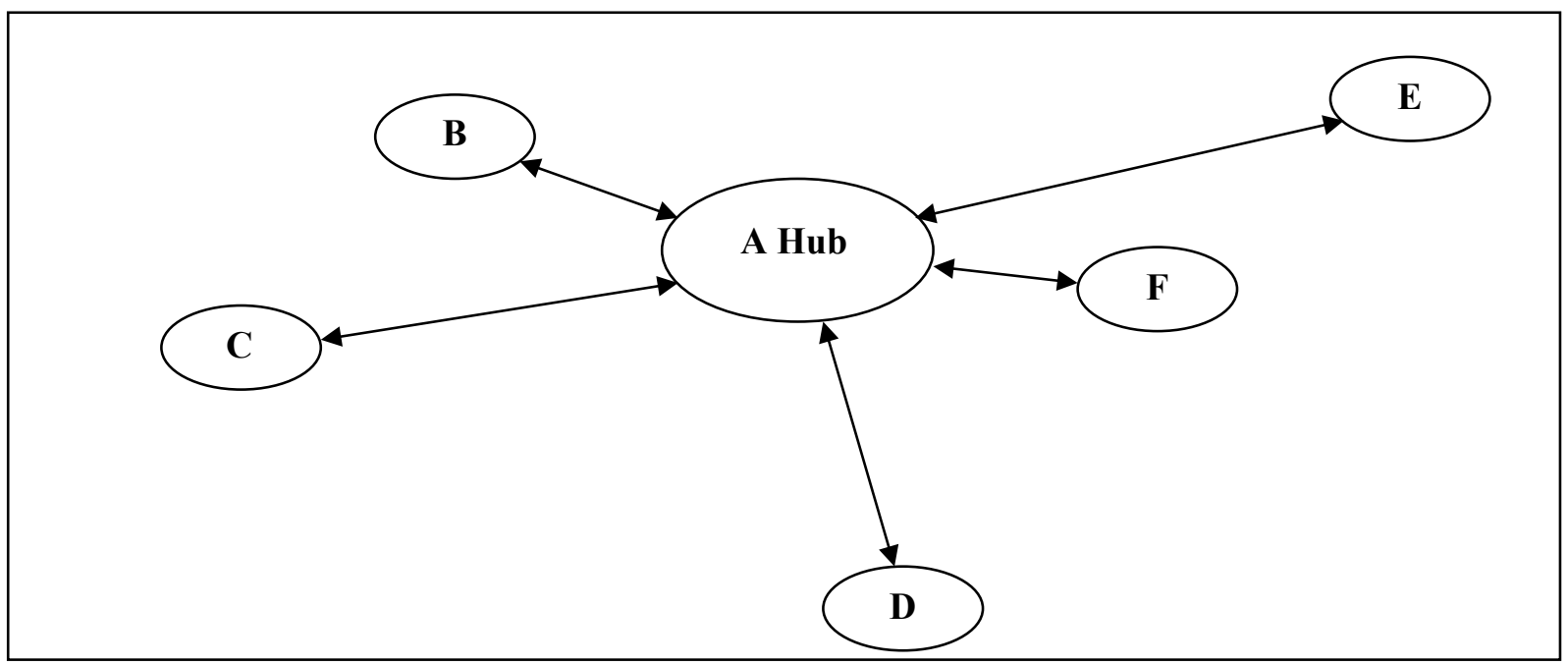

Airport locations, ICAO codes and countries (Table 1) are not specified in my hypothetical airline. Students should choose real airports when they are setting up their own airline.

TABLE 1

AIRPORTS

\begin{tabular}{|c|c|c|}
\hline Airport location (City/Hub) & Airport ICAO code & Country \\
\hline A & TBA & TBA \\
\hline B & TBA & TBA \\
\hline C & TBA & TBA \\
\hline D & TBA & TBA \\
\hline E & TBA & TBA \\
\hline F & TBA & \\
\hline
\end{tabular}

TBA - To Be Advised

The flight stage distances are set by me (Table 2). Students should apply the real Great Circle Distances. It is seen from the table that there is a mix of medium-haul and long-haul flights. The aim is to demonstrate the impact of the network effect on the revenue output (see Chapter 3.3).

TABLE 2

FLIGHT STAGE DISTANCES BY GCD (km)

\begin{tabular}{|c|c|c|c|}
\hline No. & Departure Airport & Arrival Airport & Flight stage distances by GCD* (km) \\
\hline 1 & A & B & 2,200 \\
\hline 2 & B & A & 2,200 \\
\hline 3 & A & C & 8,250 \\
\hline 4 & C & A & 8,250 \\
\hline 5 & A & D & 9,200 \\
\hline 6 & D & A & 9,200 \\
\hline 7 & A & E & 8,500 \\
\hline
\end{tabular}




\begin{tabular}{|c|c|c|c|}
\hline 8 & E & A & 8,500 \\
\hline 9 & A & F & 1,600 \\
\hline 10 & F & A & 1,600 \\
\hline
\end{tabular}

GCD* Great Circle Distance

\section{Demand}

The passenger demand (Table 3) on our network is set intentionally (based on the "previous year's" actual figures). Our demand consists of both tourist and business passengers.

TABLE 3

DEMAND

\begin{tabular}{|c|c|c|c|c|}
\hline No. & City pairs (stages) & \multicolumn{3}{|c|}{ Revenue passengers (one year) } \\
\hline & & Y (Tourist) & B (Business) & Total \\
\hline 1 & A-B & 25,800 & 1,300 & 27,100 \\
\hline 2 & B-A & 25,800 & 1,300 & 27,100 \\
\hline 3 & A-C & 13,100 & 900 & 14,000 \\
\hline 4 & C-A & 13,100 & 900 & 14,000 \\
\hline 5 & A-D & 13,600 & 1,100 & 14,700 \\
\hline 6 & D-A & 13,600 & 1,100 & 14,700 \\
\hline 7 & A-E & 14,100 & 850 & 14,950 \\
\hline 8 & E-A & 14,100 & 850 & 14,950 \\
\hline 9 & A-F & 26,200 & 1,400 & 27,600 \\
\hline 10 & F-A & 26,200 & 1,400 & 27,600 \\
\hline & Total & $\mathbf{1 8 5 , 6 0 0}$ & $\mathbf{1 1 , 1 0 0}$ & $\mathbf{1 9 6 , 7 0 0}$ \\
\hline
\end{tabular}

\section{Aircraft Utilisation}

We have the "previous year's" schedule from which the number of departures per year can be defined (Table 4). I have tried to put together realistic figures.

TABLE 4

AIRCRAFT UTILIZATION

\begin{tabular}{|c|c|c|c|c|c|}
\hline No. & $\begin{array}{c}\text { City pairs } \\
\text { (stages) }\end{array}$ & Block Time (h) & Departures & $\begin{array}{c}\text { Block time/year } \\
\text { (h) }\end{array}$ & Block speed $(\mathrm{km} / \mathrm{h})$ \\
\hline 1 & A-B & 3.2 & 96 & 307.2 & 688 \\
\hline 2 & $\mathrm{~B}-\mathrm{A}$ & 3.2 & 96 & 307.2 & 688 \\
\hline 3 & $\mathrm{~A}-\mathrm{C}$ & 11.0 & 48 & 528.0 & 750 \\
\hline 4 & C-A & 11.0 & 48 & 528.0 & 750 \\
\hline 5 & A-D & 11.5 & 48 & 552.0 & 800 \\
\hline 6 & D-A & 11.5 & 48 & 552.0 & 800 \\
\hline 7 & A-E & 11.0 & 48 & 528.0 & 773 \\
\hline 8 & E-A & 11.0 & 48 & 528.0 & 773 \\
\hline 9 & $\mathrm{~A}-\mathrm{F}$ & 2.5 & 96 & 240.0 & 640 \\
\hline 10 & F-A & 2.5 & 96 & 240.0 & 640 \\
\hline & & Total & 672 & $4,310.4$ & \\
\hline & & \multicolumn{2}{|c|}{ Average utilisation (h/day) } & 11.97 & \\
\hline
\end{tabular}


Block hours are the industry standard measure of aircraft utilisation. The average daily utilisation should be around the industry average.

Reminder: The total amount of time a flight takes - from pushing back from the departure gate ("offblocks") to arriving at the destination gate ("on-blocks") - is called the "block time". Block time includes the time to taxi-out to the runway, the actual flight duration and the time to taxi to the arrival gate.

The block speed calculation is just for control to be sure that the block speed on a given route is realistic. Attention: The block speed on long routes is higher than on short routes.

\section{Type of Aircraft}

We have to be sure that from both the passenger demand and the route stage distances' perspective the potential aircraft are suitable. In our case, the average number of tourist passengers per departure is 276 , the average number of business passengers per departure is 17 and the maximum route stage distance is $9,200 \mathrm{~km}$. To meet the demand, we set a two-class seating configuration-24 business class seats (B) and 356 tourist seats (Y) - for a total of 380 seats.

The A330-200 and B777-200ER aircraft meet both conditions. Take care that the number of seats (in our case 380) does not exceed the maximum number of seats specified by the manufacturer of the aircraft by accounting for the seating configuration. Just for your information, the maximum number of seats (only tourists) in the case of the A330-200 is 406 seats and in the case of B777-200ER, 440 seats. The range of the A330-200 is $13,450 \mathrm{~km}$ and the range of the B777-200ER is $13,084 \mathrm{~km}$.

Students can choose any seating configuration. From a practical point of view, I suggest choosing a configuration applied by an airline flying the aircraft you have chosen.

\section{Available Seats}

Reminder: The annual seat capacity (Table 5) is calculated by multiplying the total number of seats per aircraft, per seating configuration by the number of departures (see in Table 4) stage-by-stage and then summing them up.

TABLE 5

\section{SEAT CAPACITY}

\begin{tabular}{|c|c|c|c|c|}
\hline & & \multicolumn{2}{|c|}{ Available seats/year } & \\
\hline No. & City pairs (stages) & Y & B & Y+B \\
\hline 1 & A-B & 34,176 & 2,304 & 36,480 \\
\hline 2 & B-A & 34,176 & 2,304 & 36,480 \\
\hline 3 & A-C & 17,088 & 1,152 & 18,240 \\
\hline 4 & C-A & 17,088 & 1,152 & 18,240 \\
\hline 5 & A-D & 17,088 & 1,152 & 18,240 \\
\hline 6 & D-A & 17,088 & 1,152 & 18,240 \\
\hline 7 & A-E & 17,088 & 1,152 & 18,240 \\
\hline 8 & E-A & 17,088 & 1,152 & 18,240 \\
\hline 9 & A-F & 34,176 & 2,304 & 36,480 \\
\hline 10 & F-A & 34,176 & 2,304 & 36,480 \\
\hline & Total & $\mathbf{2 3 9 , 2 3 2}$ & $\mathbf{1 6 , 1 2 8}$ & $\mathbf{2 5 5 , 3 6 0}$ \\
\hline
\end{tabular}

Based on the expected demand and the number of available seats, we can establish our fleet. The number of available seats $(255,360)$ covers the yearly demand $(196,700)$. The available seats can be generated with one aircraft; hence, our fleet comprises one aircraft. 


\section{OPERATIONAL AND FINANCIAL PLAN}

Our plan covers one year of operation.

\section{Available Output (Capacity)}

Reminder: Available seat kilometres (ASK) are obtained by multiplying the number of seats (see Table 5) available for sale on each flight by the flight stage distance flown (see Table 2) and then summing them up.

Aircraft kilometres flown are obtained by multiplying the number of departures (see Table 4) by the flight stage distances (by GCD) stage-by-stage and then summing them up (Table 6).

TABLE 6

CAPACITY

\begin{tabular}{|c|c|c|c|}
\hline No. & City pairs (stages) & Available output (Capacity) (ASK) & $\begin{array}{c}\text { Aircraft kilometres } \\
\text { flown }\end{array}$ \\
\hline 1 & A-B & $80,256,000$ & 211,200 \\
\hline 2 & B-A & $80,256,000$ & 211,200 \\
\hline 3 & A-C & $150,480,000$ & 396,000 \\
\hline 4 & C-A & $150,480,000$ & 396,000 \\
\hline 5 & A-D & $167,808,000$ & 441,600 \\
\hline 6 & D-A & $167,808,000$ & 441,600 \\
\hline 7 & A-E & $155,040,000$ & 408,000 \\
\hline 8 & E-A & $155,040,000$ & 408,000 \\
\hline 9 & A-F & $58,368,000$ & 153,600 \\
\hline 10 & F-A & $58,368,000$ & 153,600 \\
\hline & Total & $\mathbf{1 , 2 2 3 , 9 0 4 , 0 0 0}$ & $\mathbf{3 , 2 2 0 , 8 0 0}$ \\
\hline
\end{tabular}

\section{Summary and calculations}

\section{Indicators (network level)}

$\mathrm{P}_{\mathrm{a}}-$ Available output (Capacity) (ASK)

$\mathrm{N}_{\mathrm{s}}$ - Number of available seats

$\overline{\mathrm{l}}_{\mathrm{h}}$ - Seat-haul average $(\mathrm{km})$

$1_{\mathrm{f}}-$ Kilometres flown $(\mathrm{km})$

$\mathrm{N}_{\mathrm{d}}$ - Number of departures

$\bar{l}_{s}-$ Average stage length $(\mathrm{km})$
Value

$1,223,904,000$

255,360

4,793

$3,220,800$

672

4,793

\section{Equations used}

$$
\overline{\mathrm{l}}_{\mathrm{h}}=\frac{\mathrm{P}_{\mathrm{a}}}{\mathrm{N}_{\mathrm{s}}}
$$

$$
\overline{\mathrm{l}}_{\mathrm{s}}=\frac{\mathrm{l}_{\mathrm{f}}}{\mathrm{N}_{\mathrm{d}}}
$$

Reminder: Average stage length is the average distance flown per aircraft departure.

The seat-haul distance (in short, "seat-haul") is the average distance of hauling one aircraft seat (empty or occupied) on the network during the planned period. The definition of seat-haul we use as an explanation of the "network effect" (Chapter 3.3).

The average stage length equals seat-haul; you will find the proof in Appendix 5.2. 


\section{Revenue Output (Traffic)}

Reminder: Revenue passenger kilometres (RPK) are obtained by multiplying the number of farepaying passengers on each flight stage by flight stage distance (see Table 2) and then summing them up (Table 7).

TABLE 7

TRAFFIC (RPK)

\begin{tabular}{|c|c|c|c|}
\hline No. & City pairs (stages) & Revenue passengers & Revenue output (Traffic) (RPK) \\
\hline & & Total & \\
\hline 1 & A-B & 27,100 & $59,620,000$ \\
\hline 2 & B-A & 27,100 & $59,620,000$ \\
\hline 3 & A-C & 14,000 & $115,500,000$ \\
\hline 4 & C-A & 14,000 & $115,500,000$ \\
\hline 5 & A-D & 14,700 & $135,240,000$ \\
\hline 6 & D-A & 14,700 & $135,240,000$ \\
\hline 7 & A-E & 14,950 & $127,075,000$ \\
\hline 8 & E-A & 14,950 & $127,075,000$ \\
\hline 9 & A-F & 27,600 & $44,160,000$ \\
\hline 10 & F-A & 27,600 & $44,160,000$ \\
\hline & Total & $\mathbf{1 9 6 , 7 0 0}$ & $\mathbf{9 6 3 , 1 9 0 , 0 0 0}$ \\
\hline
\end{tabular}

\section{Indicators (network level)}

$\mathrm{P}_{\mathrm{r}}-$ Revenue output (Traffic) (RPK)

$\mathrm{N}_{\mathrm{r}}-$ Number of revenue passengers carried

$\bar{l}_{t} \quad$ - Average trip length or passenger-haul $(\mathrm{km})$

\section{Summary and calculations}

Value

$963,190,000$

196,700

4,897

\section{Equations used}

$$
\overline{1}_{t}=\frac{P_{r}}{N_{r}}
$$

\section{Load Factor}

Reminder: Passenger load factor (\%) is revenue output (RPK) expressed as a percentage of available output (ASK) (Table 8). The seat occupancy (\%) is the number of passengers carried as a percentage of seats available for sale. The load factor and the seat occupancy on a single stage are equal but, on the network, they are usually different from each other. This difference will lead us to the phenomenon of the network effect (see Chapter 3.3). 
TABLE 8

LOAD FACTOR AND SEAT OCCUPANCY

\begin{tabular}{|c|c|c|c|c|c|c|c|}
\hline No. & City pairs & $\begin{array}{c}\text { Revenue } \\
\text { output } \\
\text { (Traffic) } \\
\text { (RPK) }\end{array}$ & $\begin{array}{c}\text { Available } \\
\text { output } \\
\text { (Capacity) } \\
\text { (ASK) }\end{array}$ & $\begin{array}{c}\text { Load } \\
\text { factor }\end{array}$ & $\begin{array}{c}\text { Seat } \\
\text { passengers }\end{array}$ & $\begin{array}{c}\text { Rvailable } \\
\text { seats }\end{array}$ & $\begin{array}{c}\text { occupancy } \\
\text { or Seat } \\
\text { load factor }\end{array}$ \\
\hline 1 & A-B & $59,620,000$ & $80,256,000$ & $74.29 \%$ & 27,100 & 36,480 & $74.29 \%$ \\
\hline 2 & B-A & $59,620,000$ & $80,256,000$ & $74.29 \%$ & 27,100 & 36,480 & $74.29 \%$ \\
\hline 3 & A-C & $115,500,000$ & $150,480,000$ & $76.75 \%$ & 14,000 & 18,240 & $76.75 \%$ \\
\hline 4 & C-A & $115,500,000$ & $150,480,000$ & $76.75 \%$ & 14,000 & 18,240 & $76.75 \%$ \\
\hline 5 & A-D & $135,240,000$ & $167,808,000$ & $80.59 \%$ & 14,700 & 18,240 & $80.59 \%$ \\
\hline 6 & D-A & $135,240,000$ & $167,808,000$ & $80.59 \%$ & 14,700 & 18,240 & $80.59 \%$ \\
\hline 7 & A-E & $127,075,000$ & $155,040,000$ & $81.96 \%$ & 14,950 & 18,240 & $81.96 \%$ \\
\hline 8 & E-A & $127,075,000$ & $155,040,000$ & $81.96 \%$ & 14,950 & 18,240 & $81.96 \%$ \\
\hline 9 & A-F & $44,160,000$ & $58,368,000$ & $75.66 \%$ & 27,600 & 36,480 & $75.66 \%$ \\
\hline 10 & F-A & $44,160,000$ & $58,368,000$ & $75.66 \%$ & 27,600 & 36,480 & $75.66 \%$ \\
\hline & Total & $\mathbf{9 6 3 , 1 9 0 , 0 0 0}$ & $\mathbf{1 , 2 2 3 , 9 0 4 , 0 0 0}$ & $\mathbf{7 8 . 7 0 \%}$ & $\mathbf{1 9 6 , 7 0 0}$ & $\mathbf{2 5 5 , 3 6 0}$ & $\mathbf{7 7 . 0 3 \%}$ \\
\hline
\end{tabular}

\section{Summary and calculations}

\section{Indicators (network level)}

$\lambda$ - Passenger load factor

$\lambda_{\mathrm{s}}-$ Seat occupancy

$d_{n}-$ Network effect coefficient

Load factor cross check

$\lambda_{\mathrm{b}}-$ Break-even load factor
Value

$78.70 \%$

$77.03 \%$

1.0217

$78.70 \%$

$72.27 \%$

\section{Equations used}

$$
\begin{gathered}
\lambda=\frac{\mathrm{P}_{\mathrm{r}}}{\mathrm{P}_{\mathrm{a}}} \\
\lambda_{\mathrm{s}}=\frac{\mathrm{N}_{\mathrm{r}}}{\mathrm{N}_{\mathrm{s}}} \\
\mathrm{d}_{\mathrm{n}}=\frac{\overline{\mathrm{l}_{\mathrm{t}}}}{\overline{\mathrm{l}_{\mathrm{h}}}}
\end{gathered}
$$

$\lambda=\lambda_{\mathrm{s}} \mathrm{d}_{\mathrm{n}}$

$$
\lambda_{\mathrm{b}}=\frac{\mathrm{c}}{\mathrm{y}}
$$

Attention: Take notice of the difference between load factor and seat occupancy on the network level.

\section{Revenue and Yield}

Reminder: Yield is the average revenue collected per passenger kilometre (RPK) (Table 9). Passenger yield is calculated by dividing the total passenger revenue on a flight or on a network by the Traffic (passenger kilometres generated). 
TABLE 9

REVENUE

\begin{tabular}{|c|c|c|c|c|c|c|c|c|}
\hline \multirow[t]{2}{*}{ No. } & \multirow[t]{2}{*}{$\begin{array}{l}\text { City } \\
\text { pairs }\end{array}$} & \multicolumn{2}{|c|}{$\begin{array}{c}\text { Passenger fare } \\
\text { (average in USD) }\end{array}$} & \multicolumn{3}{|c|}{ Revenue from ticket sales (USD) } & \multirow{2}{*}{$\begin{array}{c}\text { Revenue } \\
\text { output from } \\
\text { Table } 7 \\
\text { (Traffic) } \\
\text { (RPK) }\end{array}$} & \multirow[t]{2}{*}{$\begin{array}{c}\text { Yield } \\
\text { (USD/ } \\
\text { RPK) }\end{array}$} \\
\hline & & $\mathbf{Y}$ & B & Y & B & Total & & \\
\hline 1 & A-B & 190 & 620 & $4,902,000$ & 805,350 & $5,707,350$ & 59620,000 & 0.0957 \\
\hline 2 & $\mathrm{~B}-\mathrm{A}$ & 190 & 620 & $4,902,000$ & 805,350 & $5,707,350$ & $59,620,000$ & 0.0957 \\
\hline 3 & $A-C$ & 420 & 1.330 & $5,502,000$ & $1,197,000$ & $6,699,000$ & $115,500,000$ & 0.0580 \\
\hline 4 & $\mathrm{C}-\mathrm{A}$ & 420 & 1.330 & $5,502,000$ & $1,197,000$ & $6,699,000$ & $115,500,000$ & 0.0580 \\
\hline 5 & A-D & 440 & 1.450 & $5,984,000$ & $1,595,000$ & $7,579,000$ & $135,240,000$ & 0.0560 \\
\hline 6 & $\mathrm{D}-\mathrm{A}$ & 440 & 1.450 & $5,984,000$ & $1,595,000$ & $7,579,000$ & $135,240,000$ & 0.0560 \\
\hline 7 & A-E & 430 & 1.350 & $6,063,000$ & $1,147,500$ & $7,210,500$ & $127,075,000$ & 0.0567 \\
\hline 8 & E-A & 430 & 1.350 & $6,063,000$ & $1,147,500$ & $7,210,500$ & $127,075,000$ & 0.0567 \\
\hline 9 & A-F & 140 & 590 & $3,668,000$ & 826,000 & $4,494,000$ & $44,160,000$ & 0.1018 \\
\hline 10 & F-A & 140 & 590 & $3,668,000$ & 826,000 & $4,494,000$ & $44,160,000$ & 0.1018 \\
\hline & Total & & & $52,238,000$ & $11,141,700$ & $63,379,700$ & $963,190,000$ & 0.0658 \\
\hline
\end{tabular}

\section{Indicators (network level)}

$\mathrm{R}$ - Passenger revenue (USD)

$y-$ Yield (USD/RPK)

$\bar{f}_{p}-$ Average passenger fare (USD)

Yield cross check

$\mathrm{r}$ - Unit revenue (USD/ASK)

$\mathrm{r}_{\mathrm{s}}-$ Revenue per available seat (USD)
Summary and calculations Value

$63,379,700$

0.0658

322

0.0658

0.0518

248

\section{Equations used}

$\mathrm{y}=\frac{\mathrm{R}}{\mathrm{P}_{\mathrm{r}}}$

$\overline{\mathrm{f}}_{\mathrm{p}}=\frac{\mathrm{R}}{\mathrm{N}_{\mathrm{r}}}$

$\mathrm{y}=\frac{\overline{\mathrm{f}}_{\mathrm{p}}}{\overline{\mathrm{l}}_{\mathrm{t}}}$

$\mathrm{r}=\frac{\mathrm{R}}{\mathrm{P}_{\mathrm{a}}}$

$\mathrm{r}_{\mathrm{s}}=\frac{\mathrm{R}}{\mathrm{N}_{\mathrm{s}}}$

The yield falls as average trip length increases (see equation for yield cross check), assuming a slower increase of the average fare. If we consider that fares increase with route distance not in a linear way, then, as a result, the yield will fall as average trip length increases.

Yield should decline with route distance as well. Let's see how this relationship looks like in our case (Figure 2). 
FIGURE 2

THE LONGER THE DISTANCE TO THE DESTINATION THE LOWER THE YIELD

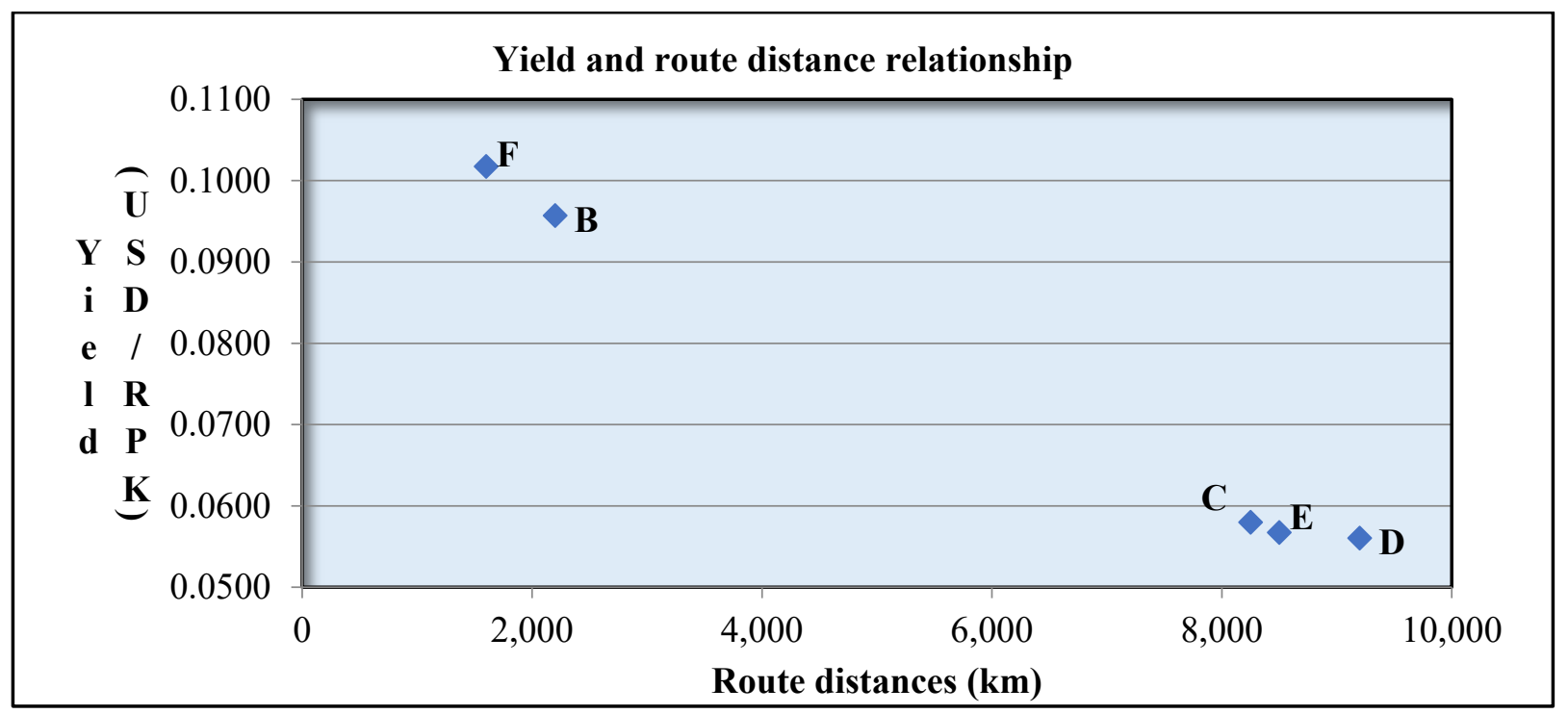

\section{Costs and Unit Cost}

Reminder: Unit cost is a measure obtained by dividing total operating cost by the Capacity (ASK). We make rough cost estimation (Table 10) based on analysis of the cost's breakdown of some airlines. Students should apply real cost estimations.

TABLE 10

COST BREAKDOWN

\begin{tabular}{|l|c|c|}
\hline \multicolumn{1}{|c|}{ Cost breakdown } & USD & Ratio (\%) \\
\hline Aircraft fuel & $13,900,000$ & $23.87 \%$ \\
\hline Wages, salaries and benefits & $15,949,500$ & $27.39 \%$ \\
\hline Airport and navigation fees & $3,900,000$ & $6.70 \%$ \\
\hline Aircraft maintenance & $4,800,000$ & $8.24 \%$ \\
\hline Depreciation & $5,740,000$ & $9.86 \%$ \\
\hline Sales and distribution costs & $3,100,000$ & $5.32 \%$ \\
\hline Communications and information technology & $1,450,000$ & $2.49 \%$ \\
\hline Other & $3,500,000$ & $6.01 \%$ \\
\hline Total excluding catering and onboard services & $\mathbf{5 2 , 3 3 9 , 5 0 0}$ & $\mathbf{8 9 . 8 7 \%}$ \\
\hline Catering and onboard services & $5,901,000$ & $10.13 \%$ \\
\hline Total operating costs & $\mathbf{5 8 , 2 4 0 , 5 0 0}$ & $\mathbf{1 0 0 . , 0 0 \%}$ \\
\hline
\end{tabular}

Summary and calculations

$\begin{array}{lll}\text { Indicators (network level) } & \text { Value } & \text { Equations us } \\ \mathrm{C}-\text { Operating costs (USD) } & 58,240,500 & \mathrm{C} \\ \mathrm{c}-\text { Unit } \operatorname{cost}(\mathrm{USD} / \mathrm{ASK}) & 0.0476 & \mathrm{c}=\frac{\mathrm{P}}{\mathrm{P}_{\mathrm{a}}}\end{array}$


$\mathrm{c}_{\mathrm{s}}-$ Average cost per seat (USD/seat)

Unit cost cross check

$\mathrm{C}_{\mathrm{p}}$ - On-board passenger services cost (USD)

$\mathrm{c}_{\mathrm{p}}$ - On-board services cost per PAX (USD) $\mathrm{c}=\frac{\mathrm{c}_{\mathrm{s}}}{\overline{\mathrm{l}}_{\mathrm{h}}}$

$5,901,000$

$$
\mathrm{c}_{\mathrm{p}}=\frac{\mathrm{C}_{\mathrm{p}}}{\mathrm{N}_{\mathrm{r}}}
$$

Modifying the number of passengers carried, ceteris paribus (all other things remaining constant), the unit cost will change because of the catering and on-board passenger service cost changes (in general because of the load-related costs change). This is the reason why the catering and the on-board passenger service cost are treated separately. This approach gives more precise results of calculations in the What-If analysis (see Chapter 3). In the case where you are creating a Low-Cost Carrier (LCC), there is no on-board passenger service cost and no need to separate this cost.

\section{Profit}

The economic result (Profit or Loss) can be calculated by using three different equations. The result should be the same in all three cases. You can find all the necessary data to calculate the Profit in Table 11.

TABLE 11

PROFIT CALCULATION

\begin{tabular}{|c|c|c|}
\hline Indicators (network level) & Value & $\overline{\text { Equations used }}$ \\
\hline E - Economic result (Profit or loss) & & \\
\hline $\mathrm{E}=$ & $5,139,200$ & 1. $\mathrm{E}=\mathrm{R}-\mathrm{C}$ \\
\hline $\mathrm{E}=$ & $5,139,200$ & 2. $E=P_{a}(\lambda y-c)$ \\
\hline $\mathrm{E}=$ & $5,139,200$ & 3. $E=P_{a}(r-c)$ \\
\hline R - Revenue (USD) & $63,379,700$ & \\
\hline C - Operating cost (USD) & $58,240,500$ & \\
\hline $\mathrm{P}_{\mathrm{a}}-$ Available output (Capacity) (ASK) & $1,223,904,000$ & \\
\hline$\lambda-$ Load factor & $78.70 \%$ & \\
\hline y - Yield (USD/RPK) & 0.0658 & \\
\hline c - Unit cost (USD/ASK) & 0.0476 & \\
\hline r - Unit revenue (USD/ASK) & 0.0518 & \\
\hline
\end{tabular}

Important notice: If you check my calculations, then you will find that the result E of Equations (2) and (3) differs from the result of Equation (1). This difference is caused by the number of decimals. The number of decimal places is four as a maximum in this paper. I have made all calculations in Excel, where the number of decimal places is limited only by the Excel program. In checking my calculations, please recalculate the load factor, yield, unit cost and unit revenue for decimals using the Excel program and the input data of Chapter 1.

\section{Operating and Financial Statistics}

A summary of the most relevant indicators of our plan is seen in Table 12. 
TABLE 12

OPERATING AND FINANCIAL STATISTICS

\begin{tabular}{|c|l|l|}
\hline No & Operation: Traffic and Capacity & Value \\
\hline 1 & Passengers carried & 196,700 \\
\hline 2 & Seat capacity (available seats) & 255,360 \\
\hline 3 & Available seat km (ASK) & $1,223,904,000$ \\
\hline 4 & Revenue passenger km (RPK) & $963,190,000$ \\
\hline 5 & Passenger load factor & $78.70 \%$ \\
\hline & Financial & \\
\hline 6 & Passenger revenue (USD) & $\mathbf{6 3 , 3 7 9 , 7 0 0}$ \\
\hline 7 & Passenger revenue per RPK (Yield) & 0.0658 \\
\hline 8 & Passenger revenue per ASK (Unit revenue) & 0.0518 \\
\hline 9 & Average passenger fare (USD/PAX) & 322 \\
\hline 10 & Revenue per available seat (USD/Seat) & 248 \\
\hline 11 & Cost of operation (USD) & $\mathbf{5 8 , 2 4 0 , 5 0 0}$ \\
\hline 12 & Unit cost (USD/ASK) & 0.0476 \\
\hline 13 & Cost per available seat (USD/Seat) & 228 \\
\hline 14 & Operating Profit (USD) & $\mathbf{5 , 1 3 9 , 2 0 0}$ \\
\hline & Additional indicators of operation & \\
\hline 15 & Seat occupancy & $\mathbf{7 7 . 0 3 \%}$ \\
\hline 16 & Break-even load factor & $\mathbf{7 2 . 3 2 \%}$ \\
\hline 17 & Number of departures & 672 \\
\hline 18 & Aircraft kilometres flown & $3,220,800$ \\
\hline 19 & Average trip length (km) & 4,897 \\
\hline 20 & Seat-haul (stage length) & 4,793 \\
\hline 21 & Network effect coefficient & 1.0217 \\
\hline
\end{tabular}

\section{WHAT-IF ANALYSIS}

We are offering Capacity for sale based on our schedule. The capacity (available output) and the unit cost can be regarded as constant in a draft plan version in which the network and the airline flight schedule finalised during the planning process. We will now answer some questions the management of our company could raise before approving the plan:

- How will we reach the same Profit target with combinations of load factor and yield (Chapter $3.1)$ ?

- What will the Profit be in the case of different load factor and yield target combinations (Chapter 3.2)?

- What is the impact of the passenger distribution change on the Traffic (Chapter 3.3)?

Based on the analysis results, management can decide whether to modify the plan or leave it as it is and approve it. We mark the original plan's data with yellow colour throughout in this chapter.

\section{Load Factor Versus Yield (Isoprofit Curves)}

There is an inverse relationship between the yield and load factor; i.e. in order to reach the same Profit when yield is decreasing, we have to increase load factor and vice versa.

We set up different numbers of passengers below and above the planned number, which results in different load factors (Table 13). It is assumed that the distribution of passengers on the network for all 
versions (from v1 to v5) is the same as in the plan; in other words, the average trip length and the network effect coefficient are the same as well.

For the load factor calculation, we use the following equation:

$$
\lambda=\frac{\mathrm{N}_{\mathrm{r}}}{\mathrm{N}_{\mathrm{s}}} \mathrm{d}_{\mathrm{n}}
$$

\section{TABLE 13}

PASSENGERS CARRIED AND THE LOAD FACTOR

\begin{tabular}{|c|c|c|c|c|}
\hline \multicolumn{5}{|c|}{ Versions } \\
\hline v1 & v2 & Plan & v4 & v5 \\
\hline \multicolumn{5}{|c|}{ Passengers carried } \\
\hline 188,700 & 192,700 & 196,700 & 200,700 & 204,700 \\
\hline \multicolumn{5}{|c|}{ Change in the number of PAX carried compared to planned } \\
\hline$-8,000$ & $-4,000$ & 0 & 4,000 & 8,000 \\
\hline $75.50 \%$ & $77.10 \%$ & $78.70 \%$ & $80.30 \%$ & $81.90 \%$ \\
\hline
\end{tabular}

Operating costs contains costs that depends on the number of passengers carried (on-board passenger service cost).

Having our 30 USD/PAX on-board passenger service cost, we recalculate the unit cost for each version (Table 14). Students can change (increase or decrease) this passenger-related cost and see how the unit cost is changing.

TABLE 14

UNIT COST IN RELATION TO NUMBER OF PASSENGERS CARRIED

\begin{tabular}{|c|c|c|c|c|}
\hline v1 & v2 & Plan & v4 & v5 \\
\hline \multicolumn{7}{|c|}{ Change in on-board passenger service cost (USD) } \\
\hline$-240,000$ & $-120,000$ & 0 & 120,000 & 240,000 \\
\hline \multicolumn{7}{|c|}{ Operating cost depending on the number of passengers carried } \\
\hline $58,000,500$ & $58,120,500$ & $58,240,500$ & $58,360,500$ & $58,480,500$ \\
\hline \multicolumn{7}{|c|}{ Unit cost depending on the number of passengers carried } \\
\hline 0.0474 & 0.0475 & 0.0476 & 0.0477 & 0.0478 \\
\hline
\end{tabular}

We set different Profit targets and calculate the yield to present the inverse relationship between load factor and yield. Our aim is to demonstrate how the same Profit target could be reached with different combinations of yield and load factor.

Remember: the available output is the same in all versions as in the plan. We calculate the yield (Table 15) using the following equation, which is derived from the Profit Equation (2) (see Table 11):

$$
y=\frac{\frac{E}{P_{a}}+c}{\lambda}
$$


TABLE 15

YIELD CALCULATIONS AND LOAD FACTOR

\begin{tabular}{|r|r|r|r|r|r|}
\hline \multirow{2}{*}{ Profit target (USD) } & \multicolumn{1}{|c|}{ v1 } & \multicolumn{1}{c|}{ v2 } & \multicolumn{1}{c|}{ Plan } & v4 & v5 \\
\cline { 2 - 6 } & \multicolumn{6}{|c|}{ Yield (USD/RPK) } \\
\hline $4,000,000$ & 0.0671 & 0.0658 & 0.0646 & 0.0635 & 0.0623 \\
\hline $5,139,200$ & 0.0683 & 0.0670 & 0.0658 & 0.0646 & 0.0635 \\
\hline $7,000,000$ & 0.0703 & 0.0690 & 0.0677 & 0.0665 & 0.0653 \\
\hline 0 & 0.0628 & 0.0616 & 0.0605 & 0.0594 & 0.0583 \\
\hline$-1,500,000$ & 0.0611 & 0.0600 & 0.0589 & 0.0579 & 0.0568 \\
\hline & \multicolumn{7}{|c|}{ Load factor (see Table 13) } \\
\hline & $75.50 \%$ & $77.10 \%$ & $78.70 \%$ & $80.30 \%$ & $81.90 \%$ \\
\hline
\end{tabular}

Our planned Profit target of 5,139,200 (USD) could be reached with any combination of an increasing load factor from $75.50 \%$ to $81.90 \%$ and decreasing yield from 0.0683 to 0.0635 (USD/RPK). We can set a loss target as well if necessary. Management can set any other Profit target and choose the most suitable combination of yield and load factor for a revised plan. We have all information to present the inverse relationship on the diagram now (Figure 3). The four million Profit target is not presented on the diagram intentionally for better transparency.

FIGURE 3
ANY COMBINATION OF THE YIELD AND THE LOAD FACTOR RESULTS IN THE PROFIT TARGET

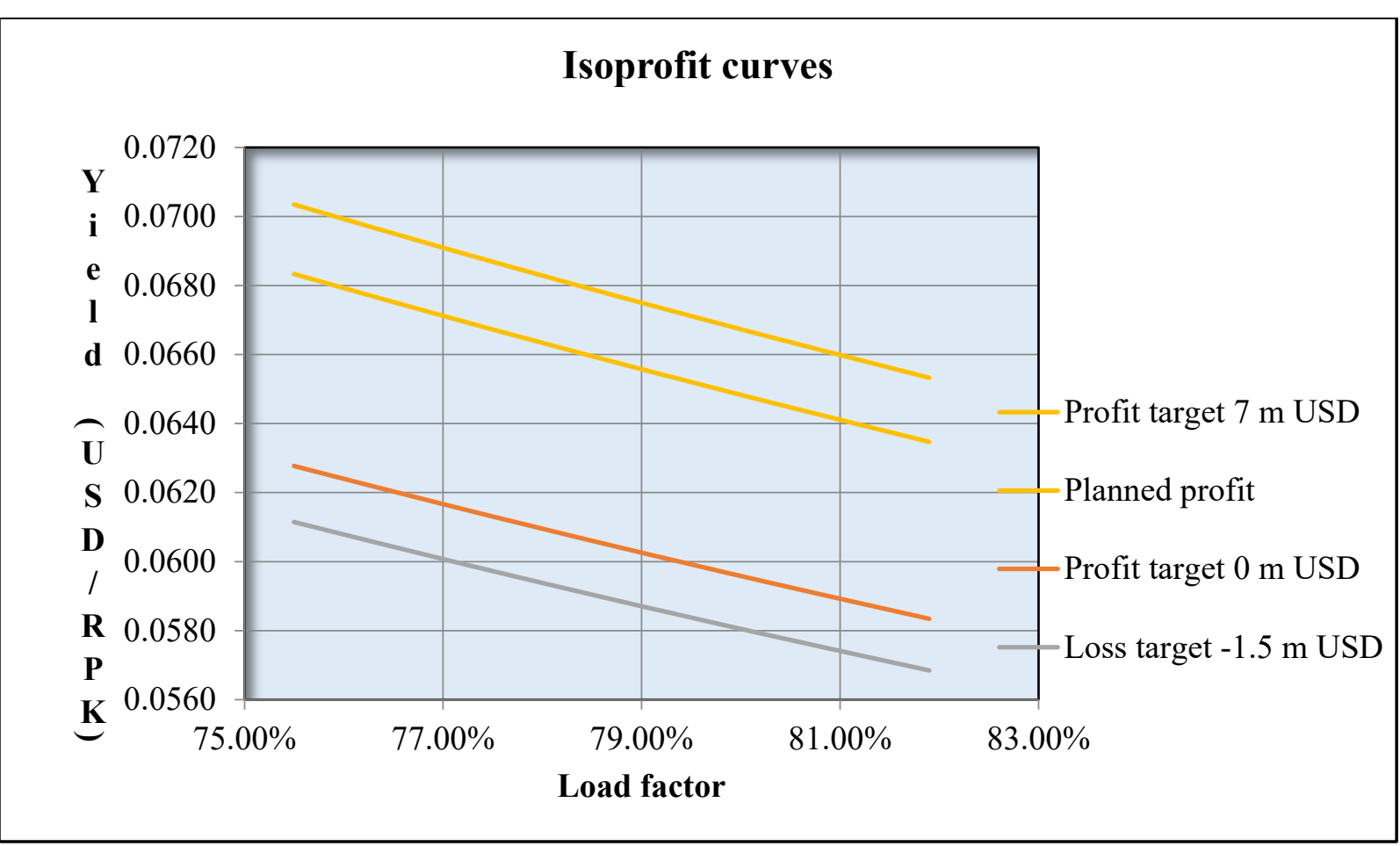

We can present how the average passenger fare is changing in relation to the yield (Table 16). We get the average passenger fare by multiplying the yield by the average trip length: 


$$
\overline{\mathrm{f}}_{\mathrm{p}}=\mathrm{y} \overline{\mathrm{l}}_{\mathrm{t}} \text {. }
$$

When the Profit equals zero, we are at the break-even point. The break-even average passenger fare is important information because below this fare the airline enters into loss.

TABLE 16

AVERAGE PASSENGER FARE

\begin{tabular}{|r|r|r|r|r|r|}
\hline \multirow{2}{*}{ Profit target (USD) } & v1 & \multicolumn{1}{c|}{ v2 } & \multicolumn{1}{c|}{ Plan } & v4 & v5 \\
\cline { 2 - 6 } & \multicolumn{6}{|c|}{ Average passenger fare (USD) } \\
\hline $4,000,000$ & 329 & 322 & 316 & 311 & 305 \\
\hline $5,139,200$ & 335 & 328 & 322 & 316 & 311 \\
\hline $7,000,000$ & 344 & 338 & 332 & 326 & 320 \\
\hline 0 (break-even) & 307 & 302 & 296 & 291 & 286 \\
\hline$-1,500,000$ & 299 & 294 & 288 & 283 & 278 \\
\hline
\end{tabular}

We now look at the revenue for every version (Table 17). We get the passenger revenue by multiplying the number of revenue passengers by the average fare.

$$
\mathrm{R}=\mathrm{N}_{\mathrm{r}} \overline{\mathrm{f}}_{\mathrm{p}}
$$

TABLE 17

REVENUE IN DIFFERENT VERSIONS

\begin{tabular}{|r|r|r|r|r|r|}
\hline \multirow{2}{*}{ Profit target (USD) } & v1 & \multicolumn{1}{|c|}{ v2 } & \multicolumn{1}{c|}{ Plan } & v4 & v5 \\
\cline { 2 - 7 } & \multicolumn{5}{|c|}{ Revenue (USD) } \\
\hline $4,000,000$ & $62,000,500$ & $62,120,500$ & $62,240,500$ & $62,360,500$ & $62,480,500$ \\
\hline $5,139,200$ & $63,139,700$ & $63,259,700$ & $63,379,700$ & $63,499,700$ & $63,619,700$ \\
\hline $7,000,000$ & $65,000,500$ & $65,120,500$ & $65,240,500$ & $65,360,500$ & $65,480,500$ \\
\hline 0 & $58,000,500$ & $58,120,500$ & $58,240,500$ & $58,360,500$ & $58,480,500$ \\
\hline$-1,500,000$ & $56,500,500$ & $56,620,500$ & $56,740,500$ & $56,860,500$ & $56,980,500$ \\
\hline
\end{tabular}

\section{Load Factor-Yield Matrix}

What will the revenue and Profit be if we apply combinations of different load factors and different yield targets?

The different load factors mean a different number of passengers and different unit costs due to the change of the passenger service cost. It is assumed that the average trip length is the same in all versions; that is, the network effect coefficient is constant (1.0217). The changes are calculated compared with the original plan's data.

We define the total number of passengers carried with the equation:

$$
\mathrm{N}_{\mathrm{r}}=\lambda \frac{\mathrm{N}_{\mathrm{s}}}{\mathrm{d}_{\mathrm{n}}}
$$

We round up the result (number of passengers) because it should be an integer.

We calculate now the unit cost depending on the number of passengers carried (Table 18). 
TABLE 18

UNIT COST DEPENDING ON THE NUMBER OF PASSENGERS CARRIED

\begin{tabular}{|c|c|c|c|c|c|}
\hline LF target & $\begin{array}{c}\text { Passengers } \\
\text { carried }\end{array}$ & $\begin{array}{c}\text { Number of PAX } \\
\text { change }\end{array}$ & $\begin{array}{c}\text { Passenger } \\
\text { service cost } \\
\text { change (USD) }\end{array}$ & $\begin{array}{c}\text { Operating } \\
\text { cost (USD) }\end{array}$ & $\begin{array}{c}\text { Unit cost } \\
\text { (USD/ASK) }\end{array}$ \\
\hline $\mathbf{7 6 . 0 0 \%}$ & 189,957 & $-6,743$ & $-202,290$ & $58,038,210$ & 0.0474 \\
\hline $\mathbf{7 8 . 0 0 \%}$ & 194,955 & $-1,745$ & $-52,350$ & $58,188,150$ & 0.0475 \\
\hline $\mathbf{7 8 . 7 0 \%}$ & 196,700 & 0 & 0 & $58,240,500$ & 0.0476 \\
\hline $\mathbf{8 0 . 0 0 \%}$ & 199,954 & 3,254 & 97,620 & $58,338,120$ & 0.0477 \\
\hline $\mathbf{8 2 . 0 0 \%}$ & 204,953 & 8,253 & 247,590 & $58,488,090$ & 0.0478 \\
\hline
\end{tabular}

To arrive at the revenue and then to the Profit, we define the related average passenger fare by multiplying the targeted yield by the average trip length, applying the equation:

$$
\overline{\mathrm{f}}_{\mathrm{p}}=\mathrm{y} \overline{\mathrm{l}}_{\mathrm{t}}
$$

As we have seen earlier in Chapter 3.1, the passenger revenue is a product of the number of revenue passengers carried and the average passenger fare:

$$
\mathrm{R}=\mathrm{N}_{\mathrm{r}} \overline{\mathrm{f}}_{\mathrm{p}}
$$

and, finally the Profit:

$$
\mathrm{E}=\mathrm{R}-\mathrm{C} \text {. }
$$

If you cross check the Profit with Equation (2) (see Table 11), then you will find a minor difference between the two results. The reason lies in the rounding up the number of passengers to make these values to be integers.

You can find the results of these calculations in Table 19.

TABLE 19

LOAD FACTOR-YIELD MATRIX

\begin{tabular}{|c|c|c|c|c|c|}
\hline \multirow{2}{*}{} & \multicolumn{5}{|c|}{ Yield target (USD/RPK) } \\
\cline { 2 - 6 } & 0.0618 & 0.0638 & 0.0658 & 0.0678 & 0.0698 \\
\cline { 2 - 6 } & \multicolumn{5}{|c|}{ Average passenger fare (USD) } \\
\cline { 2 - 6 } & 303 & 312 & 322 & 332 & 342 \\
\hline LF Target & \multicolumn{5}{|c|}{ Passenger revenue } \\
\hline $76.00 \%$ & $57,486,319$ & $59,346,661$ & $61,207,004$ & $63,067,346$ & $64,927,689$ \\
\hline $78.00 \%$ & $58,998,854$ & $60,908,144$ & $62,817,435$ & $64,726,725$ & $66,636,015$ \\
\hline $78.70 \%$ & $59,526,940$ & $61,453,320$ & $63,379,700$ & $65,306,080$ & $67,232,460$ \\
\hline $80.00 \%$ & $60,511,692$ & $62,469,940$ & $64,428,188$ & $66,386,436$ & $68,344,684$ \\
\hline $82.00 \%$ & $62,024,529$ & $64,031,735$ & $66,038,941$ & $68,046,146$ & $70,053,352$ \\
\hline
\end{tabular}




\begin{tabular}{|c|c|c|c|c|c|}
\hline & \multicolumn{5}{|c|}{$\begin{array}{c}\text { Profit } \\
\mathbf{E}=\mathbf{R}-\mathbf{C}\end{array}$} \\
\hline $76.00 \%$ & $-551,891$ & $1,308,451$ & $3,168,794$ & $5,029,136$ & $6,889,479$ \\
\hline $78.00 \%$ & 810,704 & $2,719,994$ & $4,629,285$ & $6,538,575$ & $8,447,865$ \\
\hline $78.70 \%$ & $1,286,440$ & $3,212,820$ & $5,139,200$ & $7,065,580$ & $8,991,960$ \\
\hline $80.00 \%$ & $2,173,572$ & $4,131,820$ & $6,090,068$ & $8,048,316$ & $10,006,564$ \\
\hline $82.00 \%$ & $3,536,439$ & $5,543,645$ & $7,550,851$ & $9,558,056$ & $11,565,262$ \\
\hline
\end{tabular}

Management can ask during the plan approval process; for example, what will be the Profit if we set the load factor target to $82 \%$ (increasing the number of revenue passengers) but do not increase the average fare of 322 USD?

The answer is: 7,550,851 USD. By applying different load factor and yield (average passenger fare) targets, management can fine-tune the plan to reach the desired Profit.

\section{Network Effect}

What happens if the demand for longer travel distances is prevailing over the demand for shorter travel distances?

The shift of passengers to higher travel distances (while the total number of passengers remains constant) will lead to higher revenue output and to higher Profit. Conversely, the shift of passengers to shorter travel distances (while the total number of passengers remains constant) will lead to lower revenue output and to lower Profit.

In our example, we increase the number of passengers on the long routes and decrease it on the short routes such that the number of passengers constant (Table 20). As a result, the average trip length increases (Table 22) as does the revenue output (Table 21).

TABLE 20

VERSIONS OF PASSENGER DISTRIBUTION ON THE NETWORK

\begin{tabular}{|c|c|c|c|c|c|c|c|c|}
\hline No. & $\begin{array}{c}\text { City } \\
\text { pairs }\end{array}$ & $\begin{array}{c}\text { Flight } \\
\text { stage } \\
\text { distances } \\
\text { (km) }\end{array}$ & \multicolumn{7}{|c|}{ Passengers distribution on the network (PAX) } \\
\hline & & & Plan & v1 & v2 & v3 & v4 & v5 \\
\hline 1 & A-B & 2,200 & 27,100 & 26,600 & 26,400 & 26,300 & 26,200 & 26,000 \\
\hline 2 & B-A & 2,200 & 27,100 & 26,600 & 26,400 & 26,300 & 26,200 & 26,000 \\
\hline 3 & A-C & 8,250 & 14,000 & 14,500 & 14,800 & 14,800 & 15,000 & 15,100 \\
\hline 4 & C-A & 8,250 & 14,000 & 14,500 & 14,800 & 14,800 & 15,000 & 15,100 \\
\hline 5 & A-D & 9,200 & 14,700 & 14,700 & 14,750 & 14,850 & 14,850 & 14,950 \\
\hline 6 & D-A & 9,200 & 14,700 & 14,700 & 14,750 & 14,850 & 14,850 & 14,950 \\
\hline 7 & A-E & 8,500 & 14,950 & 14,950 & 15,000 & 15,100 & 15,200 & 15,400 \\
\hline 8 & E-A & 8,500 & 14,950 & 14,950 & 15,000 & 15,100 & 15,200 & 15,400 \\
\hline 9 & A-F & 1,600 & 27,600 & 27,600 & 27,400 & 27,300 & 27,100 & 26,900 \\
\hline 10 & F-A & 1,600 & 27,600 & 27,600 & 27,400 & 27,300 & 27,100 & 26,900 \\
\hline & & Total & $\mathbf{1 9 6 , 7 0 0}$ & $\mathbf{1 9 6 , 7 0 0}$ & $\mathbf{1 9 6 , 7 0 0}$ & $\mathbf{1 9 6 , 7 0 0}$ & $\mathbf{1 9 6 , 7 0 0}$ & $\mathbf{1 9 6 , 7 0 0}$ \\
\hline
\end{tabular}


TABLE 21

\section{REVENUE OUTPUT (TRAFFIC) IN DIFFERENT VERSIONS OF} PASSENGER DISTRIBUTION

\begin{tabular}{|c|c|c|c|c|c|c|c|}
\hline \multirow{2}{*}{ No. } & $\begin{array}{c}\text { City } \\
\text { pairs }\end{array}$ & \multicolumn{7}{|c|}{ Revenue output (Traffic) (RPK) } \\
\hline & & Plan & v1 & v2 & v3 & v4 & v5 \\
\hline 1 & A-B & $59,620,000$ & $58,520,000$ & $58,080,000$ & $57,860,000$ & $57,640,000$ & $57,200,000$ \\
\hline 2 & B-A & $59,620,000$ & $58,520,000$ & $58,080,000$ & $57,860,000$ & $57,640,000$ & $57,200,000$ \\
\hline 3 & A-C & $115,500,000$ & $119,625,000$ & $122,100,000$ & $122,100,000$ & $123,750,000$ & $124,575,000$ \\
\hline 4 & C-A & $115,500,000$ & $119,625,000$ & $122,100,000$ & $122,100,000$ & $123,750,000$ & $124,575,000$ \\
\hline 5 & A-D & $135,240,000$ & $135,240,000$ & $135,700,000$ & $136,620,000$ & $136,620,000$ & $137,540,000$ \\
\hline 6 & D-A & $135,240,000$ & $135,240,000$ & $135,700,000$ & $136,620,000$ & $136,620,000$ & $137,540,000$ \\
\hline 7 & A-E & $127,075,000$ & $127,075,000$ & $127,500,000$ & $128,350,000$ & $129,200,000$ & $130,900,000$ \\
\hline 8 & E-A & $127,075,000$ & $127,075,000$ & $127,500,000$ & $128,350,000$ & $129,200,000$ & $130,900,000$ \\
\hline 9 & A-F & $44,160,000$ & $44,160,000$ & $43,840,000$ & $43,680,000$ & $43,360,000$ & $43,040,000$ \\
\hline 10 & F-A & $44,160,000$ & $44,160,000$ & $43,840,000$ & $43,680,000$ & $43,360,000$ & $43,040,000$ \\
\hline & Total & $\mathbf{9 6 3 , 1 9 0 , 0 0 0}$ & $\mathbf{9 6 9 , 2 4 0 , 0 0 0}$ & $\mathbf{9 7 4 , 4 4 0 , 0 0 0}$ & $\mathbf{9 7 7 , 2 2 0 , 0 0 0}$ & $\mathbf{9 8 1 , \mathbf { 1 4 0 , 0 0 0 }}$ & $\mathbf{9 8 6 , 5 1 0 , 0 0 0}$ \\
\hline
\end{tabular}

Reminder: Revenue output is obtained by multiplying the number of fare-paying passengers on each flight stage by the flight stage distance and then summing the results.

TABLE 22

ADDITIONAL DATA TO BUILD UP THE NETWORK EFFECT DIAGRAM (FIGURE 4)

\begin{tabular}{|l|c|c|c|c|c|c|}
\hline & Plan & v1 & v2 & v3 & v4 & v5 \\
\hline Average trip length (km) & 4,897 & 4,928 & 4,954 & 4,968 & 4,988 & 5,015 \\
\hline $\begin{array}{l}\text { Difference between the } \\
\text { average trip length and the } \\
\text { average seat-haul (km) }\end{array}$ & 104 & 135 & 161 & 175 & 195 & 222 \\
\hline Network effect coefficient & 1.0217 & 1.0281 & 1.0336 & 1.0366 & 1.0407 & 1.0464 \\
\hline Passenger load factor & $78.70 \%$ & $79.19 \%$ & $79.62 \%$ & $79.84 \%$ & $80.16 \%$ & $80.60 \%$ \\
\hline Seat occupancy & $77.03 \%$ & $77.03 \%$ & $77.03 \%$ & $77.03 \%$ & $77.03 \%$ & $77.03 \%$ \\
\hline $\begin{array}{l}\text { Traffic increase compared } \\
\text { to planned (RPK) }\end{array}$ & & $6,050,000$ & $11,250,000$ & $14,030,000$ & $17,950,000$ & $23,320,000$ \\
\hline
\end{tabular}

Just to remind you that in our plan, the average seat-haul is $4,793 \mathrm{~km}$ and the available output (Capacity) is $1,223,904,000$ ASK (see Table 6).

\section{Indicators for additional data calculations}

$\lambda$ - Passenger load factor

$\lambda_{\mathrm{s}}$ - Seat occupancy

$\overline{1}_{\mathrm{t}}$ - Average trip length or passenger-haul $(\mathrm{km})$

\section{Equations used}

$$
\begin{aligned}
\lambda & =\frac{\mathrm{P}_{\mathrm{r}}}{\mathrm{P}_{\mathrm{a}}} \\
\lambda_{\mathrm{s}} & =\frac{\mathrm{N}_{\mathrm{r}}}{\mathrm{N}_{\mathrm{s}}} \\
\overline{\mathrm{l}}_{\mathrm{t}} & =\frac{\mathrm{P}_{\mathrm{r}}}{\mathrm{N}_{\mathrm{r}}}
\end{aligned}
$$


$d_{n}-$ Network effect coefficient

$$
\mathrm{d}_{\mathrm{n}}=\frac{\overline{\mathrm{l}_{\mathrm{t}}}}{\overline{\mathrm{l}_{\mathrm{h}}}}
$$

\section{FIGURE 4}

\section{SHIFT OF PASSENGERS TO THE LONGER TRIP LENGTH RESULTS IN INCREASED LOAD FACTOR AND TRAFFIC WHILE THE SEAT OCCUPANCY (TOTAL NUMBER OF PASSENGERS) REMAINS UNCHANGED}

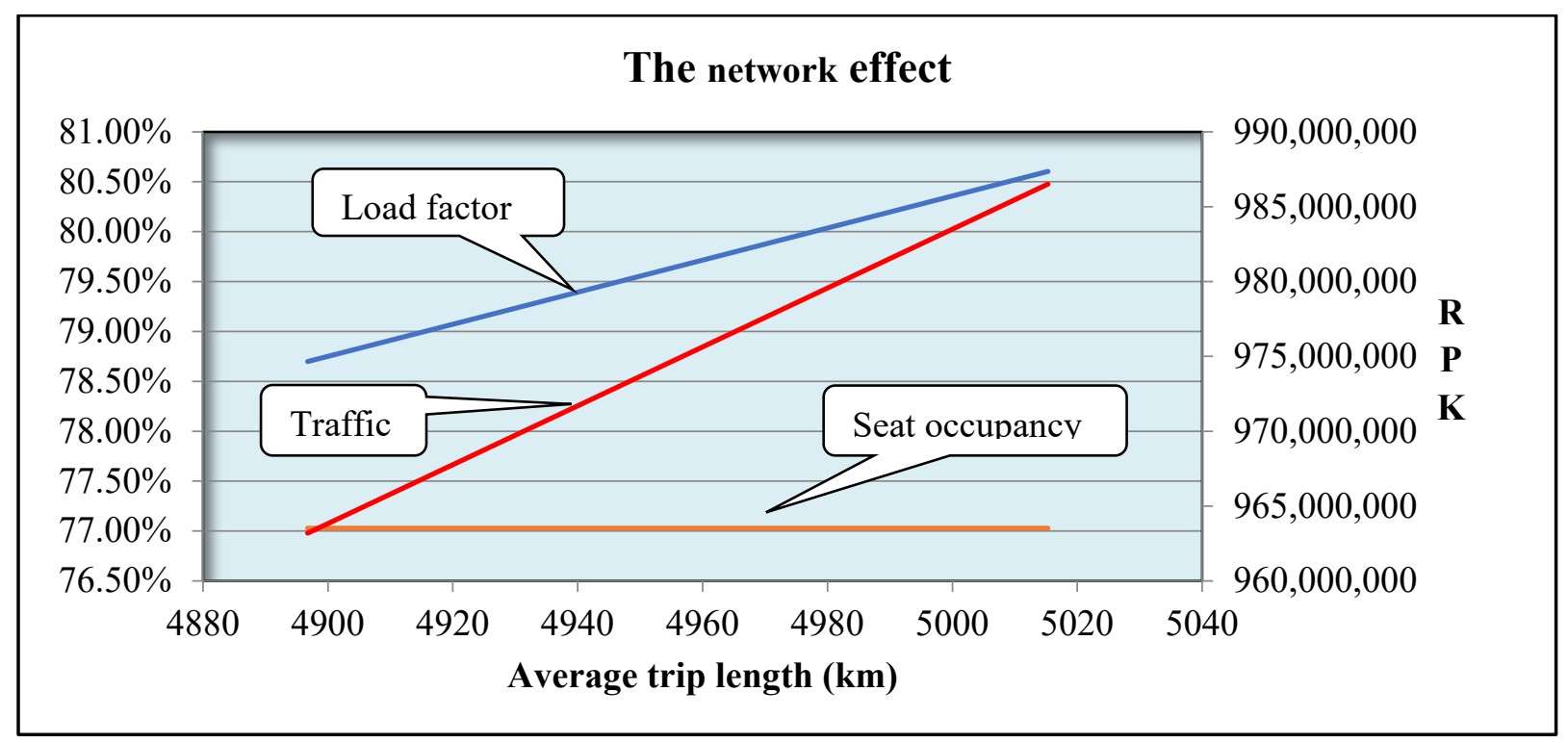

\section{CONCLUSION}

To set up an airline is much more complicated than I did in this paper. I just wanted to focus on the relationship between the Key Performance Indicators of airline economics. My intention was also to demonstrate the possible applications of the Profit model: $E=P_{a}(\lambda y-c)$. The Profit model can be used as a tool to adjust costs, yields (fares) and load factors to produce profitable combinations during the planning phase of an airline's financial plan.

Students can make the calculation more complicated compared with my version, for example, by choosing more destinations, different seat configurations, adding cargo, defining the proper aircraft type and making detailed cost calculations and building a network effect diagram when the shorter travel distances are prevailing over longer travel distances etc.

I suggest writing a software program to ease the planning and the What-If analysis calculations.

Dear Student, do not hesitate to create Your Airline!

\section{REFERENCES}

AIRBUS. (n.d.). Retrieved from https://www.airbus.com/aircraft/passenger-aircraft/a330-family/a330200.html

Boeing 777. (n.d.). Retrieved from https://en.wikipedia.org/wiki/Boeing_777

Simon, I. (n.d.). Retrieved from https://independent.academia.edu/IstvanSimon2 


\section{APPENDIX}

\section{Notation}

\begin{tabular}{|l|l|l|}
\hline Symbol & \multicolumn{1}{|c|}{ Designation } & \multicolumn{1}{c|}{ Measure } \\
\hline $\mathrm{Pa}$ & Available output (Capacity) & Available Seat Kilometres (ASK) \\
\hline $\mathrm{Pr}$ & Revenue output (Traffic) & Revenue Passenger Kilometres (RPK) \\
\hline $\mathrm{R}$ & Passenger revenue & $(\mathrm{USD})$ \\
\hline $\mathrm{C}$ & Operating costs & $(\mathrm{USD})$ \\
\hline $\mathrm{Cp}$ & On-board passenger services cost & $(\mathrm{USD})$ \\
\hline $\mathrm{E}$ & Economic result (Profit or Loss) & $(\mathrm{USD})$ \\
\hline$\lambda$ & Passenger load factor & $(\%)$ \\
\hline$\lambda \mathrm{b}$ & Break-even load factor & $(\%)$ \\
\hline$\lambda \mathrm{s}$ & Seat occupancy or seat load factor & $(\%)$ \\
\hline $\mathrm{y}$ & Yield & $(\mathrm{USD} / \mathrm{RPK})$ \\
\hline $\mathrm{c}$ & Unit cost & $(\mathrm{USD} / \mathrm{ASK})$ \\
\hline $\mathrm{cs}$ & Average cost per seat & $(\mathrm{USD} / \mathrm{seat})$ \\
\hline $\mathrm{cp}$ & Average on board passenger services cost & $(\mathrm{USD} / \mathrm{PAX})$ \\
\hline $\mathrm{Ns}$ & Number of available seats & $(\mathrm{Seats})$ \\
\hline $\mathrm{Nr}$ & Number of revenue passengers carried & $(\mathrm{PAX})$ \\
\hline $\mathrm{Nd}$ & Number of departures & \\
\hline $\mathrm{dn}$ & Network effect coefficient & \\
\hline$\overline{\mathrm{f}}_{\mathrm{p}}$ & Average passenger fare & $(\mathrm{USD})$ \\
\hline $\mathrm{r}$ & Unit revenue & $(\mathrm{USD} / \mathrm{ASK})$ \\
\hline $\mathrm{rs}$ & Revenue per available seat & $(\mathrm{USD} / \mathrm{seat})$ \\
\hline$\overline{\mathrm{l}}_{\mathrm{t}}$ & Average trip length or passenger-haul & $(\mathrm{km})$ \\
\hline$\overline{\mathrm{l}}_{\mathrm{h}}$ & Seat-haul average & $(\mathrm{km})$ \\
\hline$\overline{\mathrm{l}}_{\mathrm{s}}$ & Average stage length & $(\mathrm{km})$ \\
\hline $\mathrm{lf}$ & Kilometres flown & $(\mathrm{km})$ \\
\hline & & \\
\hline
\end{tabular}

\section{Average Stage Length and Seat-Haul}

As mentioned in the Chapter 2.1, the average stage length equals seat-haul. Here is the proof:

Average stage length:

$$
\overline{1}_{\mathrm{s}}=\frac{1_{\mathrm{f}}}{\mathrm{N}_{\mathrm{d}}}
$$

Available output can be calculated as:

$$
\mathrm{P}_{\mathrm{a}}=\overline{\mathrm{l}}_{\mathrm{h}} \mathrm{N}_{\mathrm{s}} \quad \text { or } \quad \mathrm{P}_{\mathrm{a}}=\frac{\mathrm{l}_{\mathrm{f}} \mathrm{N}_{\mathrm{s}}}{\mathrm{N}_{\mathrm{d}}}=\overline{1}_{\mathrm{s}} \mathrm{N}_{\mathrm{s}}
$$

As a consequence:

$$
\overline{1}_{\mathrm{h}} \mathrm{N}_{\mathrm{s}}=\overline{1}_{\mathrm{s}} \mathrm{N}_{\mathrm{s}}
$$

and, finally, after reduction with the number of seats:

$$
\overline{1}_{\mathrm{h}}=\overline{1}_{\mathrm{S}} \text {. }
$$

